Review

\title{
Zinc-Binding Cysteines: Diverse Functions and Structural Motifs
}

\author{
Nicholas J. Pace and Eranthie Weerapana * \\ Department of Chemistry, Boston College, 2609 Beacon Street, Chestnut Hill, MA 02467, USA; \\ E-Mail: nicholas.pace@bc.edu \\ * Author to whom correspondence should be addressed; E-Mail: eranthie.weerapana@bc.edu; \\ Tel.: +1-617-552-2931; Fax: +1-617-552-2705.
}

Received: 6 February 2014; in revised form: 19 March 2014 / Accepted: 20 March 2014 / Published: 17 April 2014

\begin{abstract}
Cysteine residues are known to perform essential functions within proteins, including binding to various metal ions. In particular, cysteine residues can display high affinity toward zinc ions $\left(\mathrm{Zn}^{2+}\right)$, and these resulting $\mathrm{Zn}^{2+}$-cysteine complexes are critical mediators of protein structure, catalysis and regulation. Recent advances in both experimental and theoretical platforms have accelerated the identification and functional characterization of $\mathrm{Zn}^{2+}$-bound cysteines. $\mathrm{Zn}^{2+}$-cysteine complexes have been observed across diverse protein classes and are known to facilitate a variety of cellular processes. Here, we highlight the structural characteristics and diverse functional roles of $\mathrm{Zn}^{2+}$-cysteine complexes in proteins and describe structural, computational and chemical proteomic technologies that have enabled the global discovery of novel $\mathrm{Zn}^{2+}$-binding cysteines.
\end{abstract}

Keywords: zinc; cysteine; zinc-cysteine complexes; zinc fingers; zinc inhibition; regulatory zinc

\section{Introduction}

When considering biologically relevant transition metals, zinc is the second most abundant found within cells, behind only iron. Zinc ions $\left(\mathrm{Zn}^{2+}\right)$ are known to facilitate diverse protein functions that are essential for life. Common $\mathrm{Zn}^{2+}$ ligands found within proteins include cysteine (S), histidine (N), aspartate $(\mathrm{O})$, and glutamate $(\mathrm{O})$ residues. The ionization state of the thiol group of cysteine governs its ability to bind metals, including $\mathrm{Zn}^{2+}$. The $\mathrm{pK}_{\mathrm{a}}$ of the thiol group of cysteine is typically close to physiological $\mathrm{pH}$ (7.4) [1]; therefore, the ionization state of cysteine is highly sensitive to small 
changes within the local protein environment [2]. Thus, the affinity of cysteine for $\mathrm{Zn}^{2+}$ varies accordingly for each individual cysteine within a protein scaffold. These resulting complexes contribute to protein structure, catalysis, and regulation (Figure 1) [3,4]. $\mathrm{Zn}^{2+}$-containing protein structural motifs are best highlighted by the well-characterized zinc fingers, first discovered over 25 years ago [5-7]. Although less common, $\mathrm{Zn}^{2+}$-cysteine complexes also catalyze enzymatic transformations in diverse classes such as oxidoreductases, transferases, and hydrolases. More recently, the potential for $\mathrm{Zn}^{2+}$ to modulate protein activities has been established. These regulatory complexes proceed through distinct mechanisms, such as $\mathrm{Zn}^{2+}$-inhibition, redox-switches, and stabilization of protein interfaces [8-10]. Lastly, the cysteine-rich metallothioneins tightly regulate cellular $\mathrm{Zn}^{2+}$ levels by storing and properly redistributing $\mathrm{Zn}^{2+}$ throughout the cell [11]. Due to these diverse functional roles of $\mathrm{Zn}^{2+}$-cysteine complexes, the development of both experimental and theoretical approaches has been paramount in the identification and characterization of $\mathrm{Zn}^{2+}$-binding cysteines. Here we summarize key examples of functional $\mathrm{Zn}^{2+}$-cysteine complexes, and discuss recent advances in computational and proteomic technologies to study these complexes.

Figure 1. Zinc ions $\left(\mathrm{Zn}^{2+}\right)$ have the ability to be chelated to cysteine residues within protein scaffolds. These resulting $\mathrm{Zn}^{2+}$-cysteine complexes participate in a variety of functional roles, including structural, catalytic, regulatory and transport. Regulatory mechanisms consist of inhibitory, redox-switches, and protein-interface stabilization.

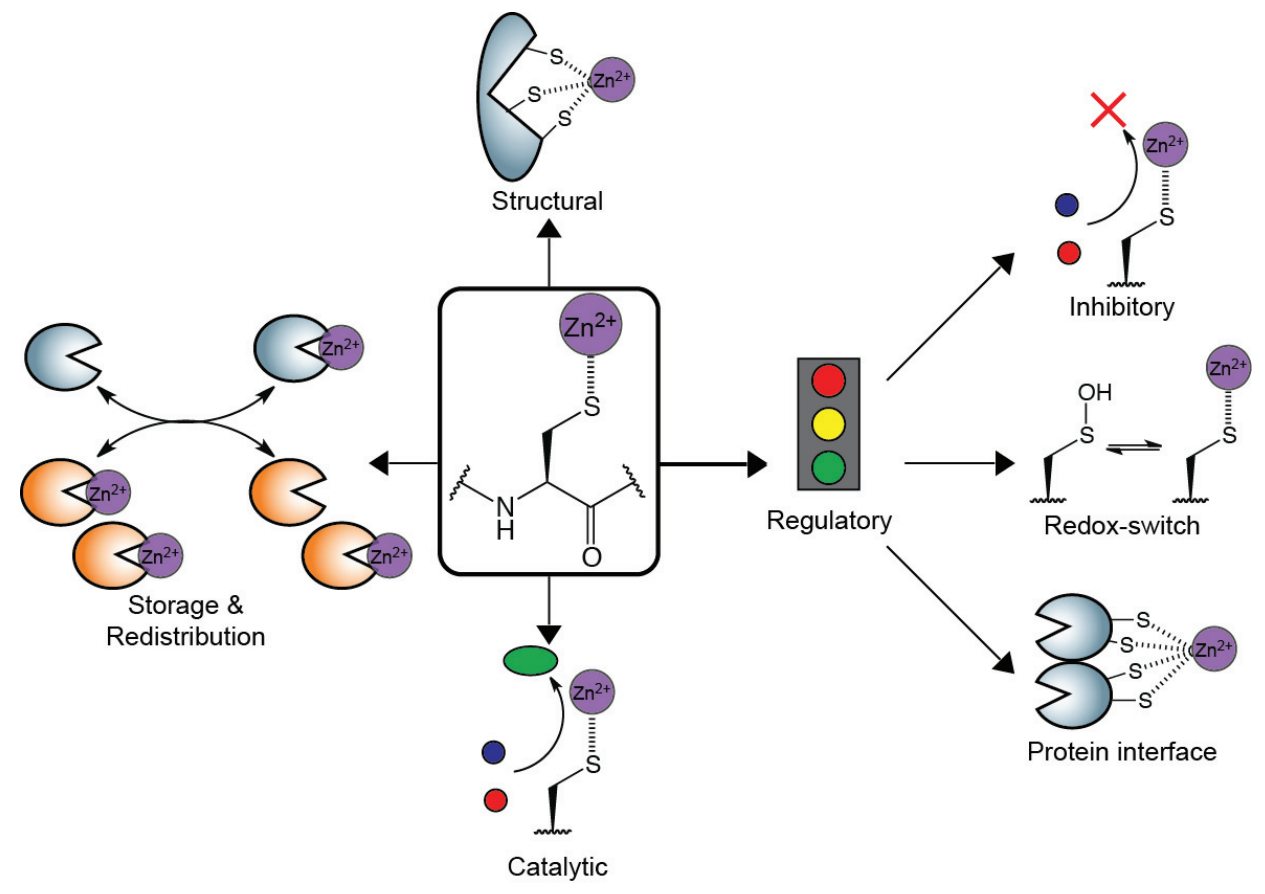

\section{Structural $\mathrm{Zn}^{2+}$-Cysteine Complexes: Zinc Fingers}

Because zinc is a d10 transition metal, it exclusively forms a $\mathrm{Zn}^{2+}$ ion and typically lacks redox activity within cells. $\mathrm{Zn}^{2+}$ typically is found to assemble coordination complexes with four ligands in a tetrahedral geometry. Recent studies estimate the human proteome consists of approximately 3000 $\mathrm{Zn}^{2+}$-proteins [12]. Of the potential $\mathrm{Zn}^{2+}$ ligands within proteins, the sulfur atom of cysteine transfers the most charge over to the $\mathrm{Zn}^{2+}$. As cysteine occupies more ligand sites, it often quenches the ability 
of the $\mathrm{Zn}^{2+}$ to act as a lewis acid, rendering these complexes relatively inert [13]. As a result, $\mathrm{Zn}^{2+}$-cysteine complexes traditionally perform structural roles within proteins. The most abundant class of structural $\mathrm{Zn}^{2+}$-cysteine complexes is the zinc finger, and these have been extensively classified [14]. Zinc fingers are characteristically comprised of $\mathrm{Cys}_{4}$ or $\mathrm{Cys}_{2} \mathrm{His}_{2}$ coordination environments [12]. The classical $\mathrm{Cys}_{2} \mathrm{His}_{2}$ zinc finger chelates a single $\mathrm{Zn}^{2+}$ within an $\alpha$-helix and antiparallel $\beta$-sheet (Figure 2 inset) [15]. Zinc finger domains are typically found in clusters of four or more within a single protein, and often structurally stabilize the protein for interaction with other proteins and biomolecules, such as DNA and RNA.

Figure 2. Three zinc fingers motifs bound within the major groove of a DNA strand with a single zinc finger motif being highlighted (black box). $\mathrm{Zn}^{2+}$ (purple) is bound to two cysteine and two histidine ligands within an $\alpha$-helix and antiparallel $\beta$-sheet. Variable sequences at the $-1,2,3$, and 6 residues of the $\alpha$-helix (yellow) dictate preferential binding to specific nucleotide sequences. (PDB ID: 1A1J).

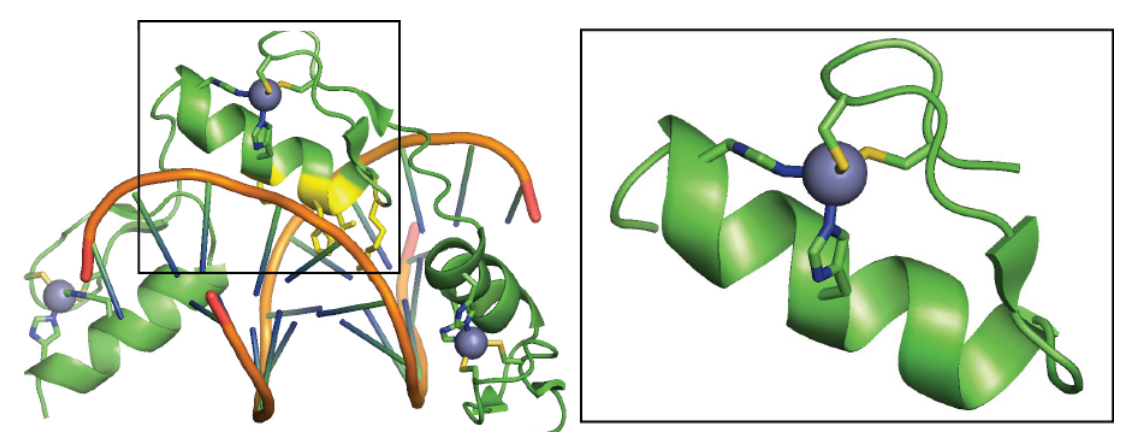

Although the functional roles of most zinc finger proteins are poorly understood, most annotated proteins act as transcription activators or suppressors [7]. A single zinc finger possesses four amino acids at the $-1,2,3$, and 6 positions of the $\alpha$-helix that participate in hydrogen-bond interactions with 3-4 nucleic acids within the major groove of DNA (Figure 2) [16]. Different sequences at these four positions preferentially bind to distinct nucleic acid sequences with high affinity and selectivity [16]. Consequently, this motif has been exploited in the development of zinc finger endonucleases for genetic engineering. By conjugating specific arrays of zinc fingers to a promiscuous FokI endonuclease, DNA can be cut at an indicated sequence to disrupt, add, or correct the gene of interest [17]. The development of a conserved linker sequence was vital to the construction of polymeric zinc-finger endonucleases, requiring DNA sequences of up to $18 \mathrm{bp}$ for recognition [18]. This advance provided enough specificity to target single genes within the human genome $[19,20]$. The expansion of synthetic zinc finger endonucleases has extended genetic engineering across diverse gene families [17].

\section{Catalytic $\mathrm{Zn}^{2+}$-Cysteine Complexes}

Beyond structural roles, cysteines bind $\mathrm{Zn}^{2+}$ to directly facilitate enzymatic transformations. Cysteines are less common ligands in catalytic $\mathrm{Zn}^{2+}$ complexes due to the steric bulk of sulfur and greater charge transfer compared to histidine and water ligands [13]. However, catalytic $\mathrm{Zn}^{2+}$-cysteine complexes have been observed across diverse enzyme classes, such as oxidoreductases, hydrolases, and transferases (Table 1). The exact mechanism varies within each individual enzyme, but typically is 
comprised of either substrate coordination or activation by $\mathrm{Zn}^{2+}$. Alcohol dehydrogenase enzymes $(\mathrm{ADH})$ were first discovered to require a $\mathrm{Zn}^{2+}$ for catalysis over 50 years ago [21]. These evolutionarily conserved enzymes facilitate the interconversion between alcohols and ketones or aldehydes. Humans possess six distinct classes of ADH enzymes (ADH1-ADH6), each utilizing the $\mathrm{Zn}^{2+}$-dependent catalytic mechanism [22]. The active enzyme is a dimer, with each $40 \mathrm{kD}$ monomer possessing a substrate-binding $\mathrm{Zn}^{2+}$ and an $\mathrm{NAD}^{+}$cofactor $[23,24]$. In the case of ADH5, the catalytic $\mathrm{Zn}^{2+}$ is bound to Cys46, His66, Cys174, and the alcohol substrate (Figure 3a) [25]. The bound $\mathrm{Zn}^{2+}$ coordinates the substrate in the correct geometry for the sequential proton transfer to Ser48 followed by hydride transfer to $\mathrm{NAD}^{+}$(Figure 3b) [26]. Although they do not directly interact with the substrate, these cysteine residues are highly conserved throughout human ADH enzyme classes and are essential for ADH activity [22].

Table 1. Representative human proteins containing catalytic $\mathrm{Zn}^{2+}$-cysteine complexes.

\begin{tabular}{|c|c|c|c|c|}
\hline Protein & Enzyme Class & Function & Mechanism & PDB Structure \\
\hline Alcohol dehydrogenase & Oxidoreductase & $\begin{array}{l}\text { Interconverts alcohols to } \\
\text { aldehydes and ketones }\end{array}$ & $\begin{array}{l}\mathrm{Zn}^{2+} \text {-coordination } \\
\text { of substrate }[23]\end{array}$ & $1 \mathrm{MC5}[25]$ \\
\hline Sorbitol dehydrogenase & Oxidoreductase & $\begin{array}{l}\text { Reversible conversion of } \\
\text { sorbitol to fructose }\end{array}$ & $\begin{array}{l}\mathrm{Zn}^{2+} \text {-activation of } \\
\text { nucleophilic water } \\
\text { molecule [27] }\end{array}$ & 1PL7 [27] \\
\hline Cytidine deaminase & Hydrolase & $\begin{array}{l}\text { Irreversible hydrolytic deamination } \\
\text { of cytidine to uridine }\end{array}$ & $\begin{array}{l}\mathrm{Zn}^{2+} \text {-activation of } \\
\text { nucleophilic water } \\
\text { molecule }[28,29]\end{array}$ & $2 \mathrm{KEM}[30]$ \\
\hline GTP cyclohydrolase I & Hydrolase & $\begin{array}{l}\text { Converts GTP to dihydroneopterin } \\
\text { triphosphate }\end{array}$ & $\begin{array}{l}\mathrm{Zn}^{2+} \text {-activation of } \\
\text { nucleophilic water } \\
\text { molecule }[31]\end{array}$ & $1 \mathrm{FB} 1[31]$ \\
\hline $\begin{array}{l}\text { Betain-homocysteine } \\
\text { methyltransferase }\end{array}$ & Transferase & $\begin{array}{l}\text { Transfers methyl group from betaine } \\
\text { to homocysteine, forming dimethyl } \\
\text { glycine and methionine }\end{array}$ & $\begin{array}{l}\mathrm{Zn}^{2+} \text {-activation of } \\
\text { thiol of homocysteine } \\
\text { substrate [32] }\end{array}$ & $1 \mathrm{LT} 8[32]$ \\
\hline $\begin{array}{l}\text { Protein } \\
\text { farnesyltransferase }\end{array}$ & Transferase & $\begin{array}{l}\text { Post-translational addition of farnesyl } \\
\text { to cysteine residues within proteins }\end{array}$ & $\begin{array}{l}\mathrm{Zn}^{2+} \text {-activation of thiol } \\
\text { on target protein }[33,34]\end{array}$ & 1JCQ [35] \\
\hline
\end{tabular}

While $\mathrm{ADH}$ acts through a $\mathrm{Zn}^{2+}$-substrate coordination mechanism, farnesyl transferase (FTase) relies on the activation of the substrate thiol by $\mathrm{Zn}^{2+}$ for its activity. FTase is part of the prenyltransferase protein family and catalyzes the post-translational addition of the 15-carbon farnesyl isoprenoid to proteins such as Ras, Rho, and Rab [36,37]. The isoprenoid is attached through a thioether linkage to a cysteine residue within a $C$-terminal $\mathrm{CaaX}$ peptide and is required for proper protein function by mediating membrane association and protein-protein interactions [38]. $\mathrm{A} \mathrm{Zn}^{2+}$ is coordinated to Asp297, Cys299, and His362 within the active site of the $\beta$ subunit of FTase (Figure 3c) [35]. The cysteine residue of the protein substrate coordinates to the $\mathrm{Zn}^{2+}$, displacing either a water or an Asp ligand. The adjacently bound farnesyl diphosphate is now vulnerable to nucleophilic attack by the $\mathrm{Zn}^{2+}$-activated thiol, resulting in the release of inorganic phosphate $\left(\mathrm{PP}_{\mathrm{i}}\right)$ and the farnesylated protein (Figure 3d) [33,34]. It's important to note that ADH and FTase represent only two possible $\mathrm{Zn}^{2+}$-depended enzymatic mechanisms, and many others have been observed as well. In an alternative mechanism, cytodine deaminase employs a $\mathrm{Zn}^{2+}$ bound by a histidine, two cysteines, and a water 
molecule to irreversibly deaminate cytidine to uridine [30]. In this case, the water molecule becomes activated and acts as the nucleophile that facilitates the transformation [28,29]. These described catalytic mechanisms refute the common misconception that $\mathrm{Zn}^{2+}$-cysteine complexes are only capable of serving structural roles within proteins.

Figure 3. (a) The active site of $\mathrm{ADH} 5$ contains a $\mathrm{Zn}^{2+}$ (purple) bound to two cysteines (Cys46, Cys174, red) a histidine (His66, blue), and $S$-hydroxymethyl glutathione as the alcohol substrate (cyan). This positions the alcohol in the correct geometry to the adjacent $\mathrm{NAD}^{+}$cofactor (yellow) (PDB ID: 1MC5); (b) The bound $\mathrm{Zn}^{2+}$ facilitates sequential proton transfers from the alcohol substrate to Ser48, NAD ${ }^{+}$, and His51, while also properly positioning the alcohol for a hydride transfer to $\mathrm{NAD}^{+}$. A generalizable "R" group is included in the structure of the primary alcohol, allowing for variability in the exact structure of the alcohol substrate. Figure adapted from Hammes-Schiffer and Benkovic [26]; (c) The active site of FTase contains a $\mathrm{Zn}^{2+}$ (purple) coordinated to Asp297 (orange), Cys299 (red), His362 (blue) and the thiol-containing target peptide (yellow) adjacent to the farnesyl diphosphate (cyan) (PDB ID: 1JCQ); (d) The cysteine of the target peptide is able to displace either an Asp297 or water ligand. The now-activated thiol forms a thioether linkage to the farnesyl group of farnesyl diphosphate, and is released by ligand exchange with Asp297 or water. Figure adapted from Ramos et al. [34].

a.

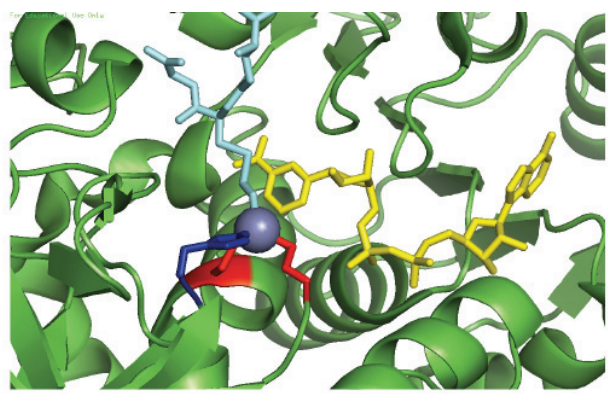

c.

d.

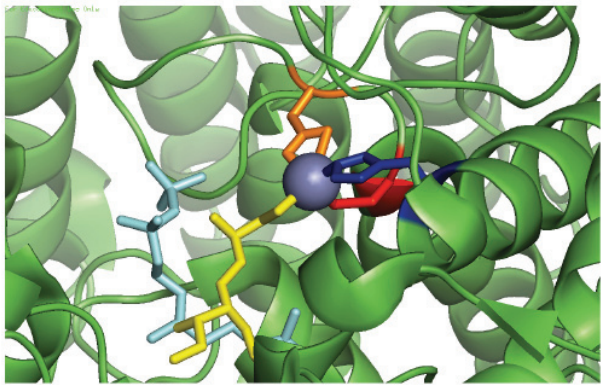

b.

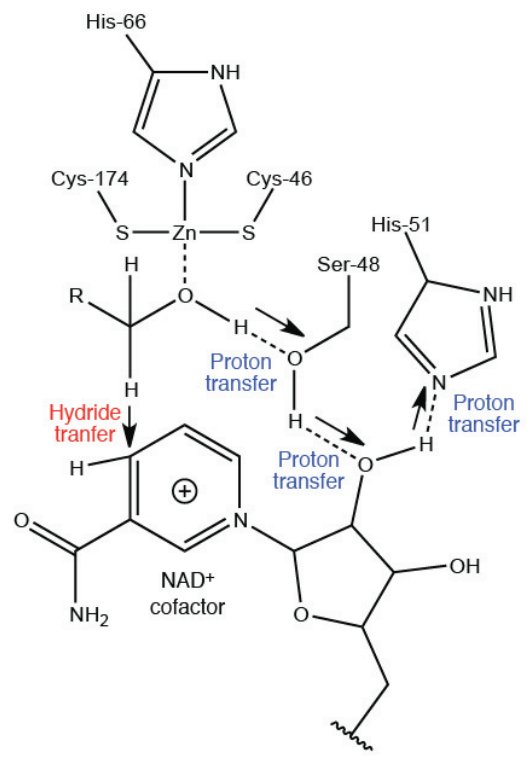

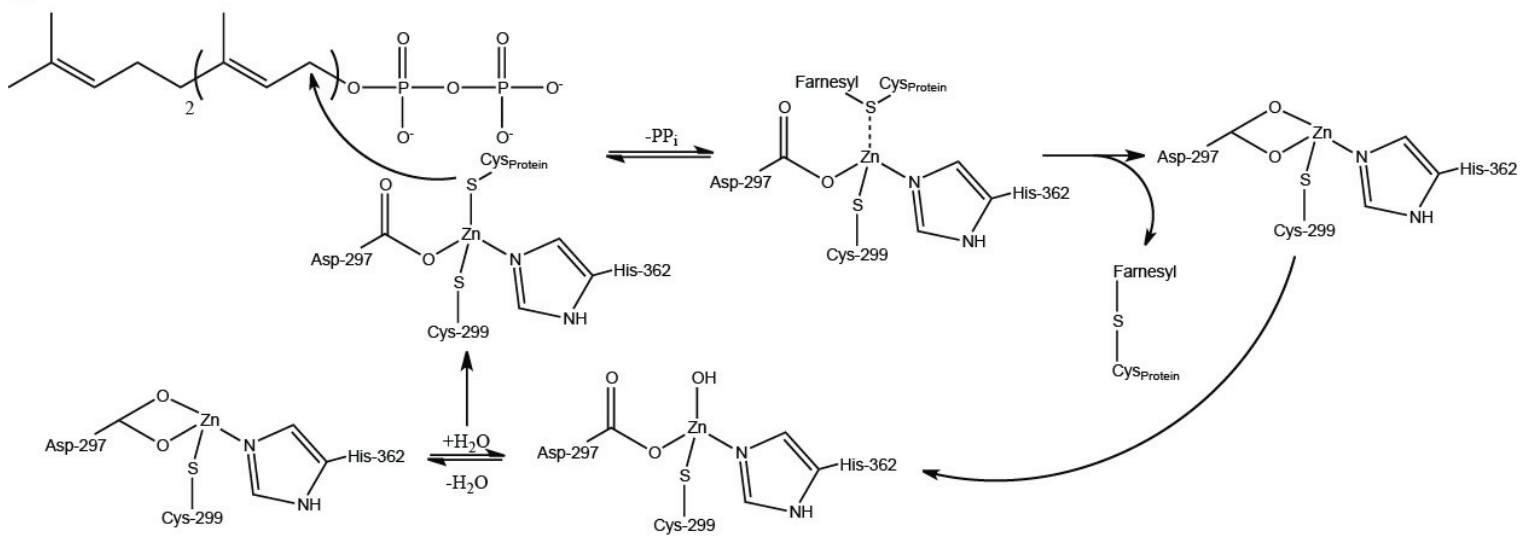




\section{Regulatory $\mathrm{Zn}^{2+}$-Cysteine Complexes}

Additionally, cysteine residues also have been observed to bind $\mathrm{Zn}^{2+}$ to modulate protein activities. In these cases, $\mathrm{Zn}^{2+}$-binding must be more transient in nature to allow for interchange between the bound and apo-forms. As a result, these cysteines are often more challenging to identify. Characterized regulatory mechanisms range in complexity, and have been categorized as inhibitory, redox-switches, and protein interface $\mathrm{Zn}^{2+}$-cysteine complexes (Table 2).

Table 2. Representative human proteins containing regulatory $\mathrm{Zn}^{2+}$-cysteine complexes.

\begin{tabular}{|c|c|c|c|c|}
\hline Protein & Enzyme Class & Function & Mechanism & PDB Structure \\
\hline $\begin{array}{l}\text { Dimethylarginine } \\
\text { dimethylaminohydrolase }\end{array}$ & Hydrolase & $\begin{array}{c}\text { Converts } \mathrm{N} \text {-omega, } \mathrm{N} \text {-omega-methyl-L- } \\
\text { arginine to dimethylamine } \\
\text { and L-citrulline }\end{array}$ & Inhibitory [39] & $2 \mathrm{CI} 7[40]$ \\
\hline $\begin{array}{l}\text { Ornithine } \\
\text { transcarbamoylase }\end{array}$ & Transferase & $\begin{array}{l}\text { Converts carbamoyl phosphate and } \\
\text { ornithine to citrulline and phosphate }\end{array}$ & Inhibitory [41] & $1 \mathrm{EP} 9[42]$ \\
\hline Cathepsin S & Protease & Lysosomal cysteine protease & Inhibitory $[8,43]$ & $2 \mathrm{HH} 5[43]$ \\
\hline Caspase 3 & Protease & Cysteine protease & Inhibitory $[44,45]$ & - \\
\hline Caspase 6 & Protease & Cysteine protease & Inhibitory [46] & $4 \mathrm{FXO}[46]$ \\
\hline Caspase 9 & Protease & Cysteine protease & Inhibitory [47] & 1JXQ [47] \\
\hline Aconitase 2 & Isomerase & Converts citrate to iso-citrate & Inhibitory [48] & - \\
\hline $\begin{array}{c}\text { Glutathione } \\
S \text {-transferase omega }\end{array}$ & Transferase & $\begin{array}{c}\text { Conjugates glutathione to a } \\
\text { variety of electrophiles }\end{array}$ & Inhibitory [49] & - \\
\hline $\begin{array}{l}\text { Betain-homocysteine } \\
\text { methyltransferase }\end{array}$ & Transferase & $\begin{array}{c}\text { Transfers methyl group from betaine } \\
\text { to homocysteine, forming dimethyl } \\
\text { glycine and methionine }\end{array}$ & Redox-switch [32] & 1LT7, 1LT8 [32] \\
\hline Protein kinase $\mathrm{C}$ & Kinase & Phosphorylates serines and threonines & Redox-switch [50] & 3PFQ [51] \\
\hline Nitric oxide synthase & Oxidoreductase & Produces nitric oxide from arginine & $\begin{array}{c}\text { Protein interface [52]; } \\
\text { Redox-switch [53] }\end{array}$ & 3 NOS $[52]$ \\
\hline Apo2L/TRAIL & Cytokine & $\begin{array}{l}\text { Induces signaling pathways } \\
\text { to trigger apoptosis }\end{array}$ & Protein interface [54] & 1DG6 [54] \\
\hline
\end{tabular}

\subsection{Inhibitory $\mathrm{Zn}^{2+}$-Cysteine Complexes}

Cysteine residues have been found to bind $\mathrm{Zn}^{2+}$ as a means of inhibiting enzymatic activity [8]. Inhibition usually occurs by chelation of $\mathrm{Zn}^{2+}$ to the catalytic cysteine residue, but allosteric inhibition attributed to $\mathrm{Zn}^{2+}$-binding at a cysteine distal to the active site has also been described (Table 2).

Dimethylarginine dimethylaminohydrolase (DDAH-1) is a metabolic enzyme responsible for the conversion of dimethylarginine to dimethylamine and citrulline. Dimethylarginine is known to inhibit nitric oxide synthases to mitigate the production of nitric oxide, an important cell signaling molecule [55]. The most well-studied DDAH-1 is from bovine, however, the human homologue retains $94 \%$ sequence homology. $\mathrm{Zn}^{2+}$ inhibits DDAH-1 activity with a $\mathrm{K}_{\mathrm{i}}$ of $4.2 \mathrm{nM}$ at $\mathrm{pH} 7.4$ [39]. This value is rather high when considering the physiological range of available $\mathrm{Zn}^{2+}$ concentrations and is suggestive of a weaker, more transient binding mode that is indicative of a regulatory role for $\mathrm{Zn}^{2+}$ within DDAH-1. The enzyme functions through a nucleophilic cysteine residue (Cys274) conserved in both the human and bovine proteins [56]. Structural studies reveal a $\mathrm{Zn}^{2+}$ bound to the catalytic Cys274 and His173 within the active site of the enzyme (Figure 4a) [40]. The remaining two ligands are comprised of 
water molecules stabilized by hydrogen-bonding to adjacent Asp79 and Glu78. DDAH-1 only possesses two $\mathrm{Zn}^{2+}$ ligands instead of the typical three or four, which may contribute to the weaker, more transient $\mathrm{Zn}^{2+}$ binding.

Figure 4. (a) The active site of dimethylarginine dimethylaminohydrolase (DDAH-1) is capable of binding $\mathrm{Zn}^{2+}$ to inhibit activity. $\mathrm{Zn}^{2+}$ (purple) is bound to the catalytic Cys274 (red) and His173 (blue). The remaining two ligands consist of water molecules (white) stabilized by hydrogen-bonding to Asp79 and Glu78 (orange) (PDB ID: 2CI7); (b) Caspase-9 has been shown to bind $\mathrm{Zn}^{2+}$ at the catalytic dyad consisting of Cys239 and His237, along with Cys287 (red), and also to Cys272, Cys230, and His224, (orange), which is found distal to the active site, to inhibit enzyme activity (PDB ID: 1JXQ); (c) Under reducing conditions, betain-homocysteine methyltransferase (BHMT) binds a $\mathrm{Zn}^{2+}$ (purple) to Cys217, Cys299, and Cys300 (red). The $\mathrm{Zn}^{2+}$-cysteine complex coordinates the substrate homocysteine (cyan) to initiate catalysis (left, PDB ID: 1LT8). When exposed to oxidizing conditions, Cys217 and Cys299 (red) form a disulfide bond, resulting in the release of $\mathrm{Zn}^{2+}$ from the active site (right, PDB ID: 1LT7); (d) The $\alpha$-subunit (green) and $\beta$-subunit (blue) of endothelial nitric oxide synthase (NOS3) are dependent on a $\mathrm{Zn}^{2+}$-binding cysteines for dimerization. Cys94 and Cys99 (red) from each subunit chelate a $\mathrm{Zn}^{2+}$ (purple) to stabilize dimer formation, allowing for proper binding of the heme cofactor (orange), tetrahydrobiopferin cofactor (yellow), and homo-arginine substrate (magenta) within each active site (PDB ID: 3NOS).

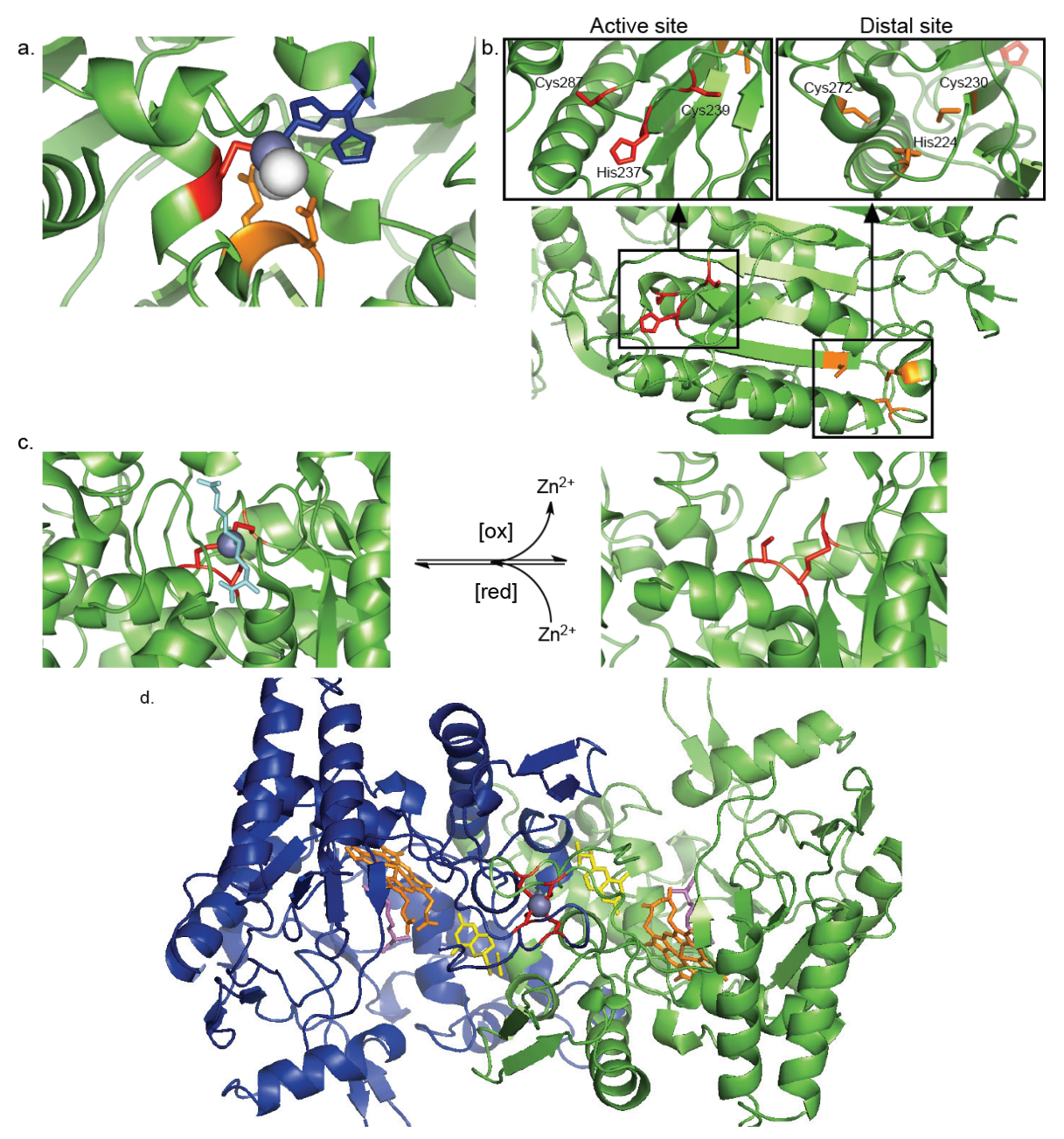


Although most inhibitory $\mathrm{Zn}^{2+}$-cysteine complexes are found to bind directly to the nucleophilic cysteine residue, the potential for allosteric inhibition has been realized in the case of Caspase-9. Caspases are cysteine-dependent aspartate-directed proteases that play a prevalent role in signaling cascades culminating in apoptosis [57]. $\mathrm{Zn}^{2+}$ has been implicated as a strict mediator of apoptosis, where small fluctuations in concentration can strongly dictate cell survival or death [58]. Caspase-9 is an initiator caspase that goes on to cleave caspase- 3 and 7 to trigger apoptosis. When attempting to decipher the mechanism of $\mathrm{Zn}^{2+}$-mediated inhibition of Caspase-9, two distinct $\mathrm{Zn}^{2+}$ binding sites were uncovered. The first consisted of the catalytic dyad, His237 and Cys239, along with the adjacent Cys287, and was primarily responsible for the $\mathrm{Zn}^{2+}$-mediated inhibition [47]. The second binding site, which comprised Cys272, Cys230 and His224, was found distal to the active site (Figure 4b). Subsequent assays suggested that this distal site may have the potential for $\mathrm{Zn}^{2+}$-mediated allosteric inhibition of Caspase-9 activity [47]. To give precedence to this notion, $\mathrm{Zn}^{2+}$-mediated allosteric inhibition has been observed in Caspase-6, however cysteines are not involved in $\mathrm{Zn}^{2+}$ coordination in this instance [46].

\subsection{Redox-Switch $\mathrm{Zn}^{2+}$-Cysteine Complexes}

Cysteine residues are susceptible to a myriad of post-translational modifications including oxidation, nitrosylation, and disulfide formation [59-61]. Cysteine's ability to bind $\mathrm{Zn}^{2+}$ is predicated upon the presence of a fully reduced, unmodified thiol. Thus, cellular redox metabolism can often be coupled to $\mathrm{Zn}^{2+}$-binding, giving rise to a "redox-switch" regulatory mechanism: increases in oxidants of sulfur release $\mathrm{Zn}^{2+}$, while reductants restore the $\mathrm{Zn}^{2+}$-binding capacity of the thiol [9]. Redox-switch $\mathrm{Zn}^{2+}$-cysteine complexes have been found to modulate diverse enzyme activities (Table 2). Betain-homocysteine methyltransferase (BHMT) is an essential metabolic enzyme that contributes to the biosynthesis of glycine, serine, threonine, and methionine [62]. This transformation relies on a $\mathrm{Zn}^{2+}$-cysteine complex to activate the homocysteine substrate. Under reducing conditions, Cys217, Cys299, and Cys300 chelate $\mathrm{Zn}^{2+}$ to give the active form of the enzyme (Figure 4c, left) [32]. Upon exposure to oxidative conditions, Cys217 and Cys299 form a disulfide bond resulting in the release of $\mathrm{Zn}^{2+}$ and inactivation of the enzyme (Figure 4c, right) [32]. This interplay between $\mathrm{Zn}^{2+}$-binding and disulfide formation couples the intracellular redox state to BHMT activity.

\subsection{Protein Interface $\mathrm{Zn}^{2+}$-Cysteine Complexes}

$\mathrm{Zn}^{2+}$-cysteine complexes can also bridge two proteins or protein-subunits. The dependence of protein-protein interactions on available $\mathrm{Zn}^{2+}$ levels establishes a novel mechanism to modulate protein supramolecular assembly and subsequent enzymatic activities (Table 2). Nitric oxide synthases (NOS) catalyze the formation of nitric oxide and citrulline from arginine through a complex mechanism consisting of five single-electron transfers [63]. Proper dimer formation is essential for oxidoreductase activity. Structures of the endothelial NOS isoform (NOS3) revealed a $\mathrm{Zn}^{2+}$ bound to Cys94 and Cys99 from each monomer (Figure 4d) [52]. The $\mathrm{Zn}^{2+}$-cysteine complex catalyzes proper dimer formation, a prerequisite for proper binding of the substrates and cofactors. Additionally, these $\mathrm{Zn}^{2+}$-binding cysteines appeared susceptible to redox-modifications, particularly by peroxynitrite. A recent study speculates that peroxynitrite facilitates disulfide-bond formation between Cys94 and Cys99 in each 
monomer, allowing for subsequent release of $\mathrm{Zn}^{2+}$, formation of free monomers, and disruption of enzyme activity [53]. This $\mathrm{Zn}^{2+}$-cysteine complex, employing both protein interface and redox-switch mechanisms, illustrates the potential for multifaceted protein regulation by $\mathrm{Zn}^{2+}$-binding cysteines.

\section{5. $\mathrm{Zn}^{2+}-$ Cysteine Complexes for $\mathrm{Zn}^{2+}$ Transfer \& Cellular Redistribution}

Because $\mathrm{Zn}^{2+}$ readily forms stable coordination complexes, free $\mathrm{Zn}^{2+}$ concentrations are found to be extremely low $[64,65]$. On the contrary, total cellular $\mathrm{Zn}^{2+}$ concentrations have been estimated on the order of 100 micromolar with $\mathrm{Zn}^{2+}$ being strongly buffered through a protein storage system [66]. Metallothioneins are a superfamily of low molecular weight proteins $(6-7 \mathrm{kD})$ that possess 20 cysteine residues capable of binding up to $7 \mathrm{Zn}^{2+}$ in the form of $\mathrm{Zn}_{4} \mathrm{Cys}_{11}$ and $\mathrm{Zn}_{3} \mathrm{Cys} 9$ clusters with unique geometries. These clusters have been evaluated as thermodynamically stabile, yet kinetically labile [67]. As a result, metallothionein and the apo-form, thionein, are able to rapidly donate/accept $\mathrm{Zn}^{2+}$ through ligand exchange [68]. This rapid exchange allows metallothioneins to increase the pool of available $\mathrm{Zn}^{2+}$ and provide an adequate source of $\mathrm{Zn}^{2+}$ for proteins [69]. Interestingly, while $\mathrm{Zn}^{2+}$-binding to metallothioneins has not been found to be cooperative, the cysteines of the $\mathrm{Zn}_{4} \mathrm{~S}_{11}$ bind slightly tighter than the $\mathrm{Zn}_{3} \mathrm{~S}_{9}$ cluster, producing a more fluid buffering mechanism [65]. $\mathrm{Zn}^{2+}$-complexes regulated by metallothioneins/thioneins modulate diverse protein activities such as gene expression and DNA repair [70].

\section{Methods of Identification of $\mathrm{Zn}^{2+}$-Cysteine Complexes}

Because $\mathrm{Zn}^{2+}$-binding cysteines play such essential physiological roles, strategies to identify and functionally characterize them have been thoroughly explored. The most common methods combine experimental approaches, such as structural genomics and protein NMR, and theoretical approaches, including homology searches of sequence databases [71-73]. These methods prove to be well-suited to distinguish $\mathrm{Zn}^{2+}$-binding cysteines within motifs where the structural features have been well-defined, such as zinc finger domains. However, regulatory $\mathrm{Zn}^{2+}$-cysteine complexes are more difficult to identify due to their necessary transient binding. By nature, these complexes must be more labile to allow for interchange between the $\mathrm{Zn}^{2+}$-bound and apo-protein forms. The employment of fewer protein-based ligands (one or two instead of three or four) and the use of ligands from multiple proteins or subunits at binding interfaces contribute to this transient binding ability. As a result, regulatory $\mathrm{Zn}^{2+}$-cysteine complexes are difficult to anticipate, and structures and homology searches fail to sufficiently detect them. Structure-based methods also require a high-resolution crystal structure of the protein of interest or a close homologue, and are therefore currently unable to access the entire proteome. With the ever-increasing number of recognized $\mathrm{Zn}^{2+}$-chelating proteins the ability to globally evaluate $\mathrm{Zn}^{2+}$-binding within a complex proteome has become paramount. Toward this end, a recent study developed a chemical-proteomic platform that serves as a valuable complement to previous approaches (Figure 5a) [49]. This platform exploits the reduced nucleophilicity of cysteine residues upon metal-binding by utilizing cysteine-reactive chemical probes that preferentially bind the more nucleophilic apo-form. Coupling these cysteine-reactive probes to gel and mass spectrometry-based proteomic techniques facilitates identification and quantification of the affinity of each cysteine towards $\mathrm{Zn}^{2+}$. A peptide-based probe was able to identify the Cys44 of sorbitol dehydrogenase 
(SORD), a known ligand of the catalytic $\mathrm{Zn}^{2+}$-cysteine complex, as means of validating the approach. Alternatively, the catalytic Cys32 of glutathione $S$-transferase omega 1 (GSTO1) was identified as a potential regulatory $\mathrm{Zn}^{2+}$-binding cysteine functioning through an inhibitory mechanism. The platform was extended by applying a promiscuous cysteine-reactive probe to globally identify putative $\mathrm{Zn}^{2+}$-binding cysteines across $\sim 900$ cysteines in the human proteome (Figure $5 \mathrm{~b}$ ). This strategy employs isotopic, chemically cleavable azobenzene biotin tags (Azo-H \& Azo-L) [74] that are conjugated to the $\mathrm{Zn}^{2+}$-treated and control proteomes. The populations are enriched on streptavidin, mixed, and digested with trypsin. The remaining probe-modified peptides are cleaved from the beads and analyzed by LC/LC-MS/MS. Light/heavy ratios are generated for each peptide and provide a quantitative measure of $\mathrm{Zn}^{2+}$ affinity for each modified cysteine. This proteomic study identified several well-characterized $\mathrm{Zn}^{2+}$-binding proteins, such as ADH5, as well as numerous uncharacterized proteins from functionally distinct classes. For example, Cys385 of Aconitase 2 (ACO2) was identified as $\mathrm{Zn}^{2+}$ binding. While ACO2 has demonstrated mitigated activity upon $\mathrm{Zn}^{2+}$ treatment, the mechanism of inhibition is unknown [48]. This platform suggests $\mathrm{Zn}^{2+}$ binds to a cysteine and disrupts the assembly of an iron-sulfur cluster essential for the enzyme's activity. Notably, this platform is more adept to identify regulatory $\mathrm{Zn}^{2+}$-binding cysteines because it is dependent on the presence of a certain population of the apo-protein. On the contrary, cysteines with stronger $\mathrm{Zn}^{2+}$ binding, such as $\mathrm{Zn}^{2+}$ fingers, may be more difficult to detect. This platform appears well-suited to complement previous methods to globally characterize the $\mathrm{Zn}^{2+}$-cysteine complexes.

Figure 5. (a) A chemical-proteomic platform to identify $\mathrm{Zn}^{2+}$-binding cysteines. $\mathrm{Zn}^{2+}$ is added into one proteome, while another population acts as a control. Both are subsequently treated with a cysteine-reactive chemical probe. These probes possess an electrophilic warhead that preferentially binds to the more nucleophilic, apo-form of the protein. Through the use of the alkyne handle, the platform can be coupled to gel or mass spectrometry-based analytical techniques to identify the affinity of cysteines for $\mathrm{Zn}^{2+}$; (b) The platform can be adapted to quantitative mass spectrometry through the use of isotopic, chemically cleavable azobenzene biotin tags (Azo-H and Azo-L). The Azo-H is conjugated to the control population, while the Azo- $\mathrm{L}$ is added to the $\mathrm{Zn}^{2+}$-treated population. The two populations are then mixed, enriched on streptavidin beads, and digested by trypsin. After washing, the probe-modified peptides are chemically cleaved from the beads using sodium dithionite and analyzed by LC/LC-MS/MS. Light/heavy ratios are generated for each peptide and provide a quantitative measure of $\mathrm{Zn}^{2+}$ affinity for each modified cysteine.

a.

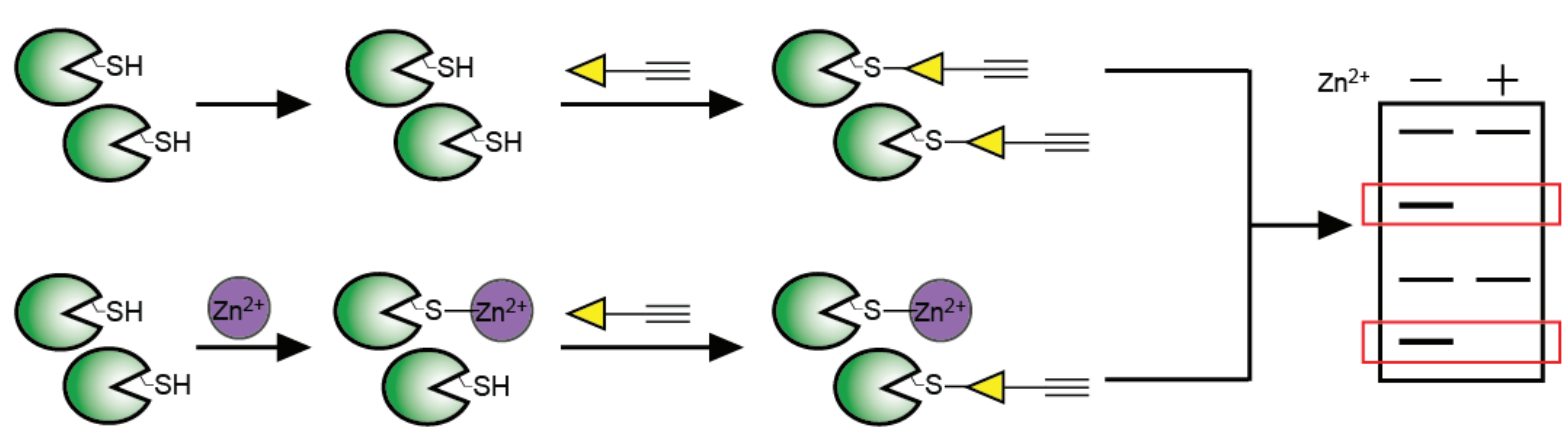


Figure 5. Cont.

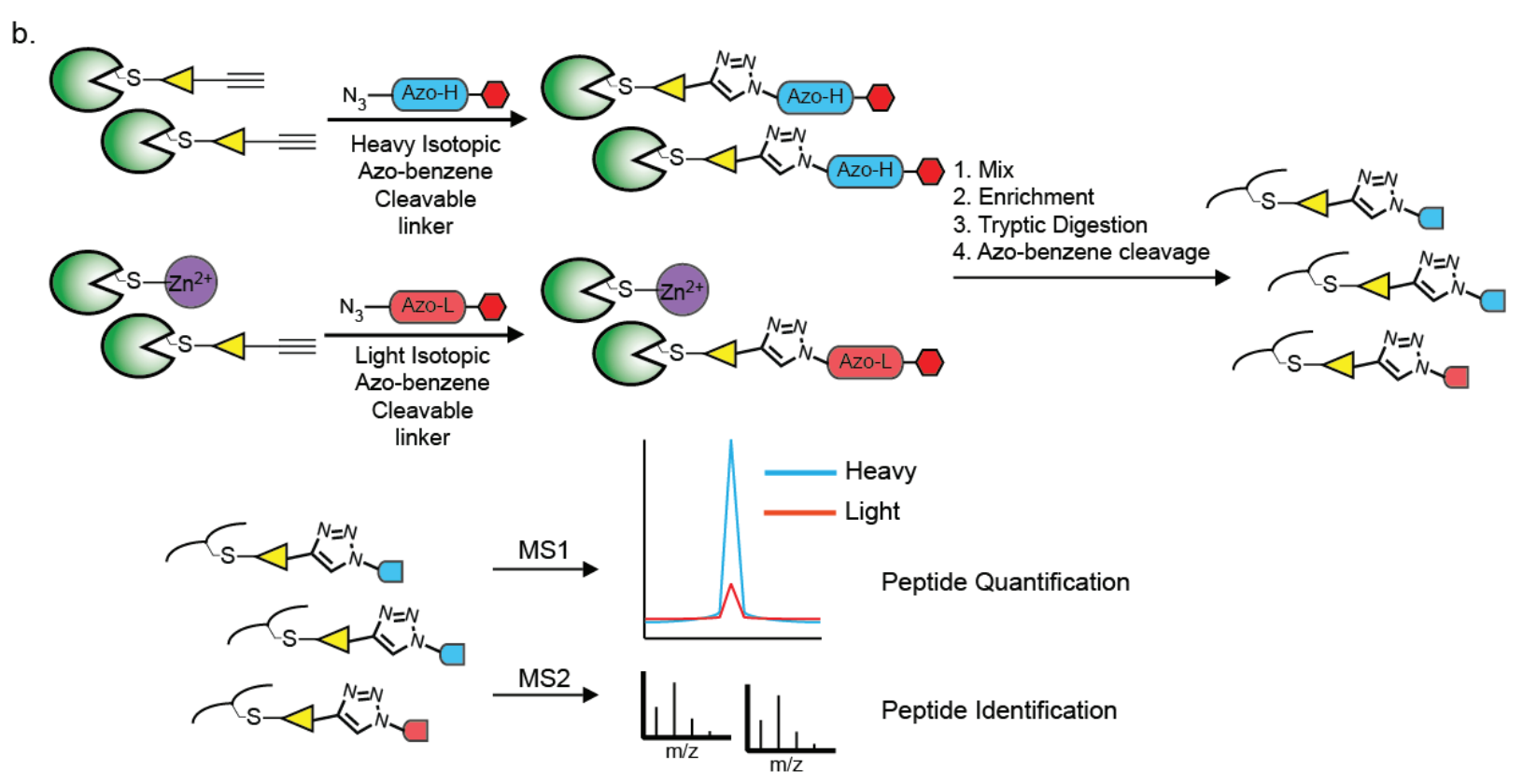

\section{Perspective and Conclusions}

While traditionally $\mathrm{Zn}^{2+}$-cysteine complexes were thought to contribute solely to protein structure through zinc finger motifs, it is now apparent that these complexes are essential for protein catalysis and regulation. Catalytic transformations that utilize $\mathrm{Zn}^{2+}$ proceed through a variety of different mechanisms, allowing for the potential of discovering alternate mechanisms not currently known. $\mathrm{Zn}^{2+}$-cysteine complexes also regulate protein activities through sophisticated mechanisms, including inhibition, redox-switching, and protein interface stabilization and new modes of $\mathrm{Zn}^{2+}$-based regulation are constantly being unveiled. The advent of structural, computational, and proteomics methods have accelerated these discoveries. Further developments in these technological platforms will help uncover more intricate and multifaceted catalytic and regulatory processes that are currently unannotated. The development of new methods is vital as we aim to expand the scope of $\mathrm{Zn}^{2+}$-cysteine complexes and their functional roles within proteins across the entire proteome.

\section{Acknowledgments}

Eranthie Weerapana is a Damon Runyon-Rachleff Innovator supported (in part) by the Damon Runyon Cancer Foundation (DRR-18-12). We are also grateful for financial support from the Smith Family Foundation and Boston College. We thank members of the Weerapana Lab for comments and critical reading of the manuscript.

\section{Author Contributions}

Nicholas J. Pace and Eranthie Weerapana contributed to reviewing literature and writing of the manuscript. 


\section{Conflicts of Interest}

The authors declare no conflict of interest.

\section{References}

1. Bulaj, G.; Kortemme, T.; Goldenberg, D.P. Ionization-reactivity relationships for cysteine thiols in polypeptides. Biochemistry 1998, 37, 8965-8972.

2. Harris, T.K.; Turner, G.J. Structural basis of perturbed pka values of catalytic groups in enzyme active sites. IUBMB Life 2002, 53, 85-98.

3. Giles, N.M.; Watts, A.B.; Giles, G.I.; Fry, F.H.; Littlechild, J.A.; Jacob, C. Metal and redox modulation of cysteine protein function. Chem. Biol. 2003, 10, 677-693.

4. Tainer, J.A.; Roberts, V.A.; Getzoff, E.D. Metal-binding sites in proteins. Curr. Opin. Biotechnol. 1991, 2, 582-591.

5. Miller, J.; McLachlan, A.D.; Klug, A. Repetitive zinc-binding domains in the protein transcription factor iiia from xenopus oocytes. EMBO J. 1985, 4, 1609-1614.

6. Klug, A. The discover of zinc fingers and their application in gene regulation and genome manipulation. Annu. Rev. Biochem. 2010, 79, 213-231.

7. Razin, S.V.; Borunova, V.V.; Maksimenko, O.G.; Kantidze, O.L. Cys $\mathrm{Chis}_{2}$ zinc finger protein family: Classification, functions, and major members. Biochemistry 2011, 77, 217-226.

8. Maret, W. Inhibitory zinc sites in enzymes. Biometals 2013, 2, 197-204.

9. Maret, W. Zinc coordination environments in proteins determine zinc functions. J. Trace Elem. Med. Biol. 2005, 19, 7-12.

10. Maret, W. New perspectives of zinc coordination environments in proteins. J. Inorg. Biochem. 2012, 111, 110-116.

11. Maret, W.; Yetman, C.A.; Jiang, L.-J. Enzyme regulation by reversible zinc inhibition: Glycerol phosphate dehydrogenase as an example. Chem. Biol. Interact. 2001, 130-132, 891-901.

12. Andreini, C.; Banci, L.; Bertini, I.; Rosato, A. Counting the zinc-proteins encoded in the human genome. J. Proteome Res. 2006, 5, 196-201.

13. Lee, Y.-M.; Lim, C. Physical basis of structural and catalytic Zn-binding sites in proteins. J. Mol. Biol. 2008, 379, 545-553.

14. Krishna, S.S.; Majumdar, I.; Grishin, N.V. Structural classification of zinc fingers: Survey and summary. Nucleic Acids Res. 2003, 31, 532-550.

15. Lee, M.S.; Gippert, G.P.; Soman, K.V.; Case, D.A.; Wright, P.E. Three-dimensional solution structure of a single zinc finger DNA-binding domain. Science 1989, 245, 635-637.

16. Wolfe, S.A.; Nekludova, L.; Pabo, C.O. Dna recognitions by $\mathrm{cys}_{2} \mathrm{his}_{2}$ zinc finger proteins. Annu. Rev. Biophys. Biomol. Struct. 1999, 3, 183-212.

17. Gaj, T.; Gersbach, C.A.; Barbas, C.F., II. ZFN, TALEN, ADN CRISPR/Cas-based methods for genome engineering. Trends Biotechnol. 2013, 31, 397-405.

18. Liu, Q.; Segal, D.J.; Ghiara, J.B.; Barbas, C.F., III. Design of polydactyl zinc-finger proteins for unique addressing within complex genomes. Proc. Natl. Acad. Sci. USA 1997, 94, 5525-5530. 
19. Beerli, R.R.; Segal, D.J.; Birgit, D.; Barbas, C.F.I. Toward controlling gene expression at will: Specific regulation of the erB-2/HER-2 promoter by using polydactyl zinc finger proteins constructed from modular building blocks. Proc. Natl. Acad. Sci. USA 1998, 95, 14628-14633.

20. Beerli, R.R.; Dreier, B.; Barbas, C.F., III. Positive and negative regulation of endogenous genes by designed transcription factors. Proc. Natl. Acad. Sci. USA 1999, 97, 1495-1500.

21. Theorell, H.; McKinley McKee, J.S. Mechanism of action of liver alcohol dehydrogenase. Nature 1961, 192, 47-50.

22. Hoog, J.-O.; Ostberg, L.J. Mammalian alcohol dehydrogenases-A comparative investigation at gene and protein levels. Chem. Biol. Interact. 2011, 191, 2-7.

23. Klinman, J.P. Probes of mechanism and transition-state structure in the alcohol dehydrogenase reaction. Crit. Rev. Biochem. Mol. Biol. 1981, 10, 39-78.

24. Pettersson, G. Liver alcohol dehydrogenase. Crit. Rev. Biochem. Mol. Biol. 1987, 21, 349-388.

25. Sanghani, P.C.; Bosron, W.F.; Hurley, T.D. Human glutathione-dependent formaldehyde dehydrogenase. Structural changes associated with ternary complex formation. Biochemistry 2002, 41, 15189-15194.

26. Hammes-Schiffer, S.; Benkovic, S.J. Relating protein motion to catalysis. Annu. Rev. Biochem. 2006, 75, 519-541.

27. Pauly, T.A.; Ekstrom, J.L.; Beebe, D.A.; Chrunyk, B.; Cunningham, D.; Griffor, M.; Kamath, A.; Lee, S.E.; Madura, R.; Mcguire, D.; et al. X-ray crystallographic and kinetic studies of human sorbitol dehydrogenase. Structure 2003, 11, 1072-1085.

28. Carter, C.W., Jr. The nucleoside deaminases for cytidine and adenosine: Structure, transistion state stabilization, mechanism, and evolution. Biochimie 1995, 77, 92-98.

29. Xiang, S.; Short, S.A.; Wolfenden, R.; Carter, C.W., Jr. Transition-state selectivity for a single hydroxyl group during catalysis by cytidine deaminase. Biochemistry 1995, 34, 4516-4523.

30. Harjes, E.; Gross, P.J.; Chen, K.-M.; Lu, Y.; Shindo, K.; Nowarski, R.; Gross, J.D.; Kotler, M.; Harris, R.S.; Matsuo, H. An extended structure of the apobec3g catalytic domain suggests a unqiue holoenzyme model. J. Mol. Biol. 2009, 389, 819-832.

31. Auerbach, G.; Herrmann, A.; Bracher, A.; Bader, G.; Gutlich, M.; Fischer, M.; Neikamm, M.; Garrido-Franco, M.; Richarson, J.; Nar, H.; et al. Zinc plays a key role in human and bacterial gtp cyclohydrolase I. Proc. Natl. Acad. Sci. USA 2000, 97, 13567-13572.

32. Evans, J.C.; Huddler, D.P.; Jiracek, J.; Castro, C.; Millian, N.S.; Garrow, T.A.; Ludwig, M.L. Betain-homocysteine methyltransferase: Zinc in a distored barrel. Structure 2002, 10, 1159-1171.

33. Long, S.B.; Casey, P.J.; Beese, L.S. Reaction path of protein farnesyltransferase at atomic resolution. Nature 2002, 419, 645-650.

34. Sousa, S.F.; Fernandes, P.A.; Ramos, M.J. Unraveling the mechanism of the farnesyltransferase enzyme. J. Biol. Inorg. Chem. 2004, 10, 3-10.

35. Long, S.B.; Hancock, P.J.; Kral, A.M.; Hellinga, H.W.; Beese, L.S. The crystal structure of human protein farnesyltransferase reveals the basis for inhibition by CaaX tetrapeptides and their mimetics. Proc. Natl. Acad. Sci. USA 2001, 98, 12948-12953.

36. Zhang, F.L.; Casey, P.J. Protein prenylation: Molecular mechanisms and functional consequences. Annu. Rev. Biochem. 1996, 65, 241-269. 
37. Ashar, H.R.; James, L.; Gray, K.; Carr, D.; Black, S.; Armstrong, L.; Bishop, W.R.; Kirschmeier, P. Farnesyl transferase inhibitors block the farnesylation of CENP-E and CENP-F and alter the association of the CENP-E with microtubules. J. Biol. Chem. 2000, 275, 30451-30457.

38. Zverina, E.A.; Lamphear, C.L.; Wright, E.N.; Fierke, C.A. Recent advances in protein prenyltransferases: Substrate identification, regulation, and disease interventions. Curr. Opin. Chem. Biol. 2012, 16, 544-552.

39. Knipp, M.; Charnock, J.M.; Garner, C.D.; Vasak, M. Structural and functional characterization of the $\mathrm{Zn}(\mathrm{II})$ site in dimethylargininase-1 (DDAH-1) from bovine brain. J. Biol. Chem. 2001, 276, 40449-40456.

40. Frey, D.; Braun, O.; Briand, C.; Vasak, M.; Grutter, M.G. Structure of the mammalian NOS regulator dimethylarginine dimethylaminohydrolase: A basis for the design of specific inhibitors. Structure 2006, 14, 901-911.

41. Lee, S.; Shen, W.-H.; Miller, A.; Kuo, L.C. $\mathrm{Zn}^{2+}$ regulation of ornithine transcarbamoylase. J. Mol. Biol. 1990, 211, 255-269.

42. Shi, D.; Morizono, H.; Tong, L.; Allewell, N.M.; Tuchman, M. Human ornithine transcarbamylase: Crystallographic insights into substrate recognition and conformational changes. Biochem. J. 2001, 354, 501-509.

43. Tully, D.C.; Liu, H.; Chatterjee, A.K.; Alper, P.B.; Epple, R.; Williams, J.A.; Roberts, M.J.; Woodmansee, D.H.; Masick, B.T.; Tumanut, C.; et al. Synthesis and SAR of arylaminoethyl amides as noncovalent inhibitors of cathepsin S: P3 cyclic ethers. Bioorg. Med. Chem. Lett. 2006, 16, 5112-5117.

44. Perry, D.K.; Smyth, M.J.; Stennicke, H.R.; Salvesen, G.S.; Duriez, P.; Poirier, G.G.; Hannun, Y.A. Zinc is a potent inhibitor of the apoptotic protease, caspase-3: A novel target for zinc in the inhibition of apoptosis. J. Biol. Chem. 1997, 272, 18530-18533.

45. Peterson, Q.P.; Goode, D.R.; West, D.C.; Ramsey, K.N.; Lee, J.J.Y.; Hergenrother, P.J. Pac-1 activates procaspase-3 in vitro through relief of zinc-mediated inhibition. J. Mol. Biol. 2009, 388, 144-158.

46. Velazquez-Delgado, E.M.; Hardy, J.A. Zinc-mediated allosteric inhibition of caspase-6. J. Biol. Chem. 2012, 287, 36000-36011.

47. Huber, K.L.; Hardy, J.A. Mechanism of zinc-mediated inhibition of caspase-9. Protein Sci. 2012, $21,1056-1065$.

48. Costello, L.C.; Liu, Y.; Franklin, R.B.; Kennedy, M.C. Zinc inhibition of mitochondrial aconitase and its importance in citrate metabolism of prostate epithelial cells. J. Biol. Chem. 1997, 272, 28875-28881.

49. Pace, N.J.; Weerapana, E. A competitive chemical-proteomic platform to identify zinc-binding cysteines. ACS Chem. Biol. 2014, 9, 258-265.

50. Korichneva, I.; Hoyos, B.; Chua, R.; Levi, E.; Hammerling, U. Zinc release from protein kinase c as the common event during activation by lipid second messenger or reactive oxygen. J. Biol. Chem. 2002, 277, 44327-44331.

51. Leonard, T.A.; Rozycki, B.; Saidi, L.F.; Hummer, G.; Hurley, J.H. Crystal structure and allosteric activation of protein kinase $\mathrm{C}$ bii. Cell 2011, 144, 55-66. 
52. Fischmann, T.O.; Hruza, A.; da Niu, X.; Fossetta, J.D.; Lunn, C.A.; Dolphin, E.; Prongay, A.J.; Reichert, P.; Lundell, D.J.; Narula, S.K.; et al. Structural characterization of nitric oxide synthase isoforms reveals striking active-site conservation. Nat. Struct. Biol. 1999, 6, 233-242.

53. Zou, M.-H.; Shi, C.; Cohen, R.A. Oxidation of zinc-thiolate complex and uncoupling of endothelial nitric oxide synthase by peroxynitrite. J. Clin. Investig. 2002, 109, 817-826.

54. Hymowitz, S.G.; O’Connell, M.P.; Ultsch, M.H.; Hurst, A.; Totpal, K.; Ashkenazi, A.; de Vos, A.M.; Kelley, R.F. A unique zinc-binding site revealed by a high-resolution X-ray structure of homotrimeric Apo2L/TRAIL. Biochemistry 2000, 39, 633-640.

55. MacAllister, R.J.; Parry, H.; Kimoto, M.; Ogawa, T.; Russell, R.J.; Hodson, H.; Whitley, G.S.J.; Vallance, P. Regulation of nitric oxide by dimethylarginine dimethylaminohydrolase. $\mathrm{Br}$. J. Pharmacol. 1996, 119, 1533-1540.

56. Wang, Y.; Monzingo, A.F.; Hu, S.; Schaller, T.H.; Robertus, J.D.; Fast, W. Developing dual and specific inhibitors of dimethylarginine dimethylaminohydrolase-1 and nitric oxide synthase: Toward a targeted polypharmacology to control nitric oxide. Biochemistry 2009, 48, 8624-8635.

57. Thornberry, N.A. The caspase family of cysteine proteases. Br. Med. Bull. 1997, 53, 478-490.

58. Zalewski, P.D.; Forbes, I.J.; Betts, W.H. Correlation of apoptosis with change in intracellular labile $\mathrm{Zn}(\mathrm{II})$ using zinquin [(2-methyl-8-p-toluenesulphonamido-6-quinolyloxy)acetic acid], a new specific fluorescent probe for Zn(II). Biochem. J. 1993, 296, 403-408.

59. Paulsen, C.E.; Carroll, K.S. Orchestrating redox signaling networks through regulatory cysteine switches. ACS Chem. Biol. 2010, 5, 47-62.

60. Klomsiri, C.; Karplus, P.A.; Poole, L.B. Cysteine-based redox switches in enzymes. Antioxid. Redox Signal. 2011, 14, 1065-1077.

61. Hess, D.T.; Matsumoto, A.; Kim, S.O.; Marshall, H.E.; Stamler, J.S. Protein S-nitrosylation: Purview and parameters. Nat. Rev. Mol. Cell Biol. 2005, 6, 150-166.

62. Pajares, M.A.; Perez-Sala, D. Betaine homocysteine $S$-methyltransferase: Just a regulator of homocysteine metabolism? Cell. Mol. Life Sci. 2006, 63, 2792-2803.

63. Stuehr, D.J. Mammalian nitric oxide synthases. Biochim. Biophys. Acta 1999, 1411, 217-230.

64. Irving, H.; Williams, R.J.P. Order of stability of metal complexes. Nature 1948, 162, 746-747.

65. Krezel, A.; Maret, W. Dual nanomolar and picomolar $\mathrm{Zn}(\mathrm{II})$ binding properties of metallothionein. J. Am. Chem. Soc. 2007, 129, 10911-10921.

66. Krezel, A.; Maret, W. Zinc-buffering capacity of a eukaryotic cell at physiological pZn. J. Biol. Inorg. Chem. 2006, 11, 1049-1062.

67. Romero-Isart, N.; Vasak, M. Advances in the structure and chemistry of metallothioneins. J. Inorg. Biochem. 2002, 88, 388-396.

68. Maret, W.; Larsen, K.S.; Vallee, B.L. Coordination dynamics of biological zinc "Clusters" in metallothioneins and in the DNA-binding domain of transcription factor Gal4. Proc. Natl. Acad. Sci. USA 1997, 94, 2233-2237.

69. Heinz, U.; Kiefer, M.; Tholey, A.; Adolph, H.-W. On the competition for available zinc. J. Biol. Chem. 2005, 280, 3197-3207.

70. Babula, P.; Masarik, M.; Adam, V.; Eckschlager, T.; Stiborova, M.; Trnkova, L.; Skutkova, H.; Provaznik, I.; Hubalek, J.; Kizek, R. Mammalian metallothioneins: Properties and functions. Metallomics 2012, 4, 739-750. 
71. Maret, W. Metalloproteomics, metalloproteomes, and the annotation of metalloproteins. Metallomics 2010, 2, 117-125.

72. Bertini, I.; Decaria, L.; Rosato, A. The annotation of full zinc proteomes. J. Biol. Inorg. Chem. 2010, 15, 1071-1078.

73. Kornhaber, G.J.; Snyder, D.; Moseley, H.N.; Montelione, G.T. Identification of zinc-ligated cysteine residues based on 13C $\alpha$ and 13C $\beta$ chemical shift data. J. Biomol. NMR 2006, 34, 259-269.

74. Qian, Y.; Martell, J.; Pace, N.J.; Ballard, T.E.; Johnson, D.S.; Weerapana, E. An isotopically tagged azobenzene-based cleavable linker for quantitative proteomics. ChemBioChem 2013, 14, 1410-1414.

(C) 2014 by the authors; licensee MDPI, Basel, Switzerland. This article is an open access article distributed under the terms and conditions of the Creative Commons Attribution license (http://creativecommons.org/licenses/by/3.0/). 